\title{
ICE-SHELF GROUNDING: ICE AND BEDROCK TEMPERATURE CHANGES
}

\author{
By Douglas R. MacAyeal* \\ (Department of Physics, University of Maine at Orono, Orono, Maine 04469, U.S.A.) \\ and Robert H. Thomas $\dagger$ \\ (Department of Geological Sciences and Institute for Quaternary Studies, University of \\ Maine at Orono, Orono, Maine 04469 , U.S.A.)
}

\begin{abstract}
Ice rises form where an ice shelf runs aground on the sea bed. After grounding occurs, basal ice temperatures cool from the sea-water temperature towards an equilibrium temperature appropriate to grounded ice. This cooling can take many thousands of years, and much of the delay is due to the thermal inertia of the bedrock. Here, we calculate transient temperature profiles for an ice rise with a final summit thickness of $520 \mathrm{~m}$ that formed by grounding of ice shelf $420 \mathrm{~m}$ thick. Seventy-five per cent cooling of the basal ice takes between 7 ooo and I I 500 years, depending on the "thermal memory" of the bedrock. This compares with an equivalent time of only I 400 years if we neglect the thermal inertia of the bedrock.

Because the surface slopes of the ice rise are related to the flow properties of the underlying ice, the summit thickness will tend to thicken as the basal ice cools. In principle, it should be possible to estimate the age of a recently-formed ice rise by examining its temperature/depth profile.

RÉsumé. Le dépôt des calottes glaciaires: changement de température de la glace et du lit rocheux. Les calottes glaciaires se forment lorsqu'une banquise s'épaissit jusqu'à atteindre le sol du lit marin. Après dépôt survient un refroidissement de la température basale de la glace depuis la température de l'eau de mer jusqu'à la température d'équilibre correspondant à l'épaisseur de glace déposée. Ce refroidissement peut demander plusieurs milliers d'années et la plus grande part de ce retard est dûe à l'inertie thermique du lit rocheux. Ici, nous calculons les profils transitoires de température pour une calotte glaciaire avec une épaisseur finale au sommet de $520 \mathrm{~m}$ qui se serait formée par le dépôt au sol d'une couverture de glace de $420 \mathrm{~m}$. Soixante quinze pour cent du refroidissement de la glace de la base demande de 7 ooo à i i 500 ans, selon la "mémoire thermique" de la roche sous-jacente. Ceci est à comparer avec une durée équivalente de seulement I 400 ans si on néglige l'inertie thermique du lit rocheux.

Comme les pentes superficielles de la calotte dépendent des propriétés de l'écoulement de la glace sousjacente, l'épaisseur au sommet tend à croître lorsque la glace de base se refroidit. En principe il serait possible d'estimer l'âge d'une calotte de formation récente en examinant un profil température/profondeur.

Zusammenfassung. Aufsitzendes Schelfeis: Änderungen der Temperatur in Eis und Untergrund. Eisaufwölbungen bilden sich dort, wo Schelfeis am Meeresgrund aufsitzt. Nach dem Aufsitzen kühlt sich das Eis am Untergrund von der Temperatur des Meerwassers auf eine Gleichgewichtstemperatur ab, die aufsitzendem Eis zukommt. Diese Abkühlung kann viele tausend Jahre beanspruchen; für einen Grossteil dieser Verzögerung ist die thermische Trägheit des Felsuntergrundes verantwortlich. Hier werden Übergangstemperaturprofile für eine Eisaufwölbung mit einer endgültigen Gipfeldicke von $520 \mathrm{~m}$ berechnet, die aus aufsitzendem Schelfeis von $420 \mathrm{~m}$ Dicke entstanden ist. $75 \%$ der Abkühlung des Untergrundeises erfordern zwischen 7 ooo und I 1500 Jahre, je nach dem "thermischen Gedächtnis" des Untergrundes. Vergleichsweise würde die entsprechende Zeit ohne Berücksichtigung der thermischen Trägheit des Untergrundes nur I 400 Jahre benötigen.

$\mathrm{Da}$ die Oberflächenneigungen einer Eisaufwölbung von den Fliesseigenschaften des darunterliegenden Eises abhängen, nimmt die Gipfeldicke mit der Abkühlung des Grundeises zu. Im Prinzip dürfte es möglich sein, das Alter einer jungen Eisaufwölbung aus ihrem Temperatur-Tiefen-Profil abzuschätzen.
\end{abstract}

THE consequences of ice-shelf grounding on an isolated bedrock high are (I) an immediate introduction of a force opposing ice motion, and (2) slow ice and bedrock cooling due to the removal of the intermediate sea-water layer. If the force opposing motion is large enough to stop the newly-grounded ice from flowing over the bedrock obstruction, then the thickness of the grounded ice will increase until a small ice dome has formed. The term ice rise is commonly given to such isolated ice domes. As the ice and bedrock cool, the summit thickness of the ice rise will increase because of the greater resistance to the ice-dome outflow provided by ice at lower temperatures (Thomas and others, I980). This increase can occur quite slowly because of the great length of time taken by the ice and bedrock to cool.

* Present address: Geophysical Fluid Dynamics Laboratory, Princeton University, Box 308, Princeton, New Jersey 08540 , U.S.A.

$\dagger$ Present address: 48 High Street, Dry Drayton, Cambridge $\mathrm{CB}_{3} 8 \mathrm{BS}$, England. 
Using a finite-element model of time-dependent vertical heat flow, we have simulated ice and bedrock cooling during ice-shelf grounding and subsequent ice-rise formation. We have chosen to restrict our simulation to conditions appropriate to the south-eastern section of the Ross Ice Shelf because of the likelihood that several new ice rises have formed there in the recent past (Thomas and Bentley, 1978). The initial ice-shelf thickness was chosen to be $420 \mathrm{~m}$, as measured in the Ross Ice Shelf Project drill hole (lat. $82^{\circ} \mathrm{S}$., long. $168^{\circ} \mathrm{W}$.) (Clough and Hansen, 1979). After grounding, the ice thickness was assumed to grow under the influence of snow accumulation until a new equilibrium thickness was attained. The values of the snow-accumulation rate and the vertical strain-rate that we used are $0.15 \mathrm{~m} /$ year (ice) and $-3.0 \times 10^{-4} /$ year, respectively. For the purpose of the calculation the present-day summit thickness of $520 \mathrm{~m}$ (Fig. I) was achieved after approximately 10000 years of growth. The

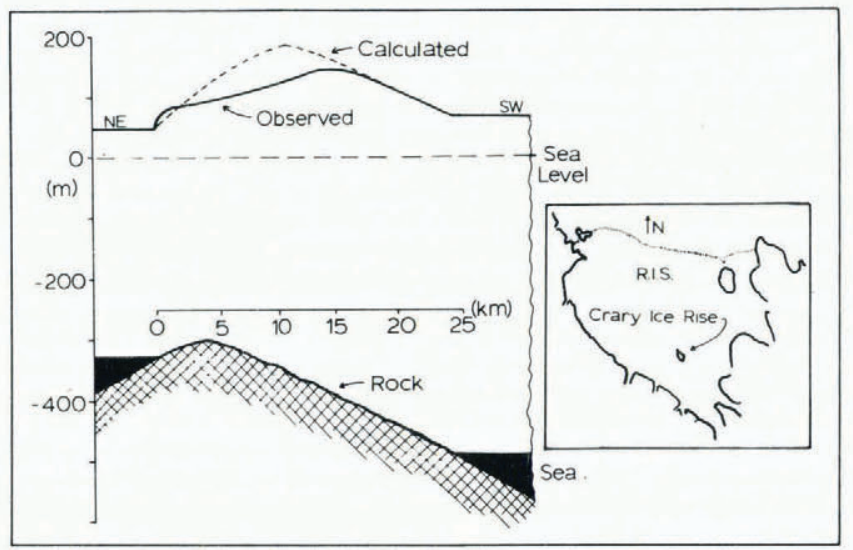

Fig. I. A sectional view of the north-east-south-west limb of the Crary Ice Rise in the Ross Ice Shelf, Antarctica.

bedrock upon which the simulated ice rise formed was assumed to have a thermal conductivity of $3.0 \mathrm{~W} \mathrm{~m} \mathrm{~W}^{-1} \mathrm{deg}^{-1}$, a thermal capacity of $800 \mathrm{~J} \mathrm{~kg}^{-1} \mathrm{deg}^{-1}$, and a density of $2700 \mathrm{~kg} \mathrm{~m}^{-3}$ (Beck, I977; Ho and others, 1978). The bedrock is known to be composed of at least some sedimentary rock (Robertson and others, in press), but because we lack information on its composition we have used thermal parameters representative of a variety of rock types. The depth to which the bedrock temperatures are modeled is $3600 \mathrm{~m}$ and is large enough so that the majority of the cooling in the ice is complete by the time cooling begins at the base of the bed-rock layer. We considered two different initial bedrock temperature-depth profiles: (I) linear, extending from $-2^{\circ} \mathrm{C}$ at the upper surface with a slope consistent with a geothermal flux of $0.06 \mathrm{~W} \mathrm{~m}^{-2}$ (Rose, 1979); and (2), a cooler, linear profile with a near-surface warming superimposed to simulate a possible "memory" of the ungrounding of the West Antarctic ice sheet during the Holocene. Throughout the simulated ice-rise formations the temperature at the upper surface of the ice rise was kept constant at $-29^{\circ} \mathrm{C}$ and the geothermal flux at the base of the $3600 \mathrm{~m}$ bedrock layer was kept constant at $0.06 \mathrm{~W} \mathrm{~m}^{-2}$. The greatest cooling occurred in the ice just above the ice-bedrock interface where temperatures reduced from $-2^{\circ} \mathrm{C}$ to $-22^{\circ} \mathrm{C}$. Seventy-five per cent of this cooling was completed after i 500 years for initial bedrock temperature-depth profile (I) and 7000 years for initial bedrock temperaturedepth profile (2). If the bedrock is assumed to have a zero heat capacity, then this time would be only I 400 years. Figure 2 displays the cooling curves for each case. Figure 3 displays a family of curves representing the temperature-depth profile through the ice and bedrock layers for case (I) at successive I ooo year intervals. 


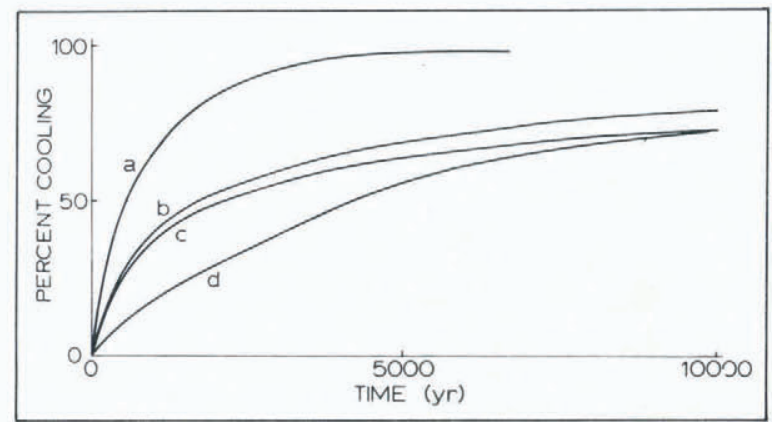

Fig. 2. The percentage of total cooling at the ice-bedrock interface beneath the summit of the Crary Ice Rise plotted against the time elapsed since ice-rise formation by ice-shelf grounding for: $(a)$ bedrock with a zero heat capacity; $(b)$ initial bedrock temperatures containing a "memory" of a previous ungrounding of the West Antarctic ice sheet; and (c) initial bedrock temperatures in steady-state equilibrium with the sea-water at the moment of ice-shelf grounding. Curve $(d)$ represents the percentage of total cooling at the ice-bedrock interface during ice-rise thinning elicited by the transformation of surrounding grounded ice into ice shelf.

Our results indicate that the temperature-depth profile within an ice rise requires a great length of time to adjust to ice-shelf grounding. The effect of this slow adjustment is a quasistatic increase in the thickness profile of the ice rise. Figure $\mathrm{I}$ shows how the thickness profile of the Crary Ice Rise (observed by R. H. Thomas and J. W. Clough) differs from that calculated assuming complete cooling of the internal ice. The method used to calculate this steady-state thickness profile is essentially the same as that used by Martin and Sanderson (1980) but it includes the effects of bedrock topography. We suggest that the difference between the calculated and the present thickness profiles is evidence of incomplete ice-rise growth resulting partly from recent formation of the ice rise and partly from incomplete cooling of the ice-rise interior and of the bedrock beneath. If our interpretation is correct, then it may be possible to determine the time elapsed since the original grounding of the Ross Ice Shelf from the temperature-depth profile of the ice rise. We point out, however, that an alternative method of formation could also produce a slow cooling of the ice-rise interior: if the Crary Ice Rise is a remnant of a larger West Antarctic ice sheet which retreated to form the present-day Ross Ice Shelf, then its internal temperatures will retain a memory of warmer conditions associated with thicker ice cover. The thermal inertia of the bedrock beneath the

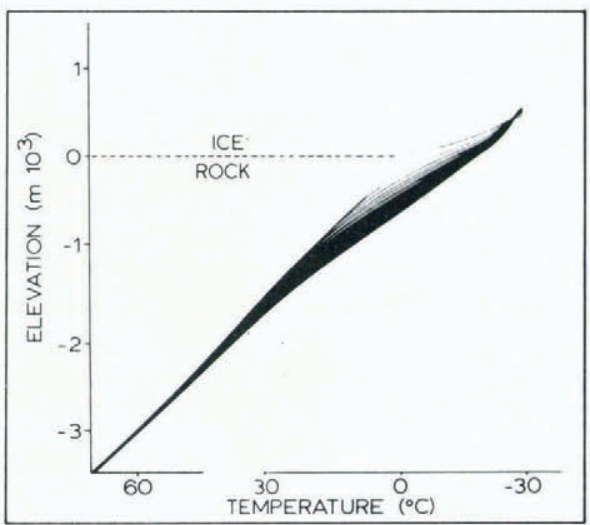

Fig. 3. The temperature-depth profile in ice and bedrock is plotted at successive 1 ooo year intervals during the formation of the Crary Ice Rise after ice-shelf grounding. The initial bedrock temperatures were in steady-state equilibrium with the sea-water immediately prior to ice-shelf grounding. 
thinning ice rise would, as in the case of the grounding ice shelf, slow cooling towards a new steady-state condition. Curve (d) in Figure i shows how the basal ice would cool from $-8^{\circ} \mathrm{C}$ to $-22^{\circ} \mathrm{C}$ during a reduction of the summit thickness from $2450 \mathrm{~m}$ to $520 \mathrm{~m}$. For this example, the initial ice thickness of $2450 \mathrm{~m}$ was derived from the CLIMAP reconstruction of the 18 ooo years B.P. West Antarctic ice sheet (personal communication from T. J. Hughes): the initial temperature-depth profile in the ice and rock was in steady-state; and the thinning was assumed to be completed in 10 ooo years. We conclude that whether the Crary Ice Rise formed by ice-shelf grounding or by surviving ungrounding during the formation of the surrounding ice shelf, the effects of slow ice and bedrock cooling are still modifying its thickness profile today.

The temperature-depth profiles resulting from our simulations of ice-rise formation are strictly valid for only the summit or spreading center of the ice rise. This is because we have neglected to treat strain heating and horizontal conduction and advection that are likely to affect the temperature-depth profiles near the ice-rise margins. We expect the magnitude of the cooling to be less away from the central part of the ice rise because of these effects. However, for a small ice rise such as the Crary Ice Rise, the effect of strain heating is small. The modification of the ice thickness profile due to a more realistic cooling will be somewhat less than that implied by the results of our calculations. Nevertheless, the influence of the bedrock beneath the ice rise can be expected to affect all parts of the ice rise, since it is superimposed upon all of the other effects which we have neglected. We stress that in all situations where grounding of an ice shelf is involved, the delayed cooling due to thermal inertia in the bedrock beneath the ice must be considered.

MS. received 2 fuly 1979 and in revised form 2 October 1979

\section{REFERENCES}

Beck, A. E. 1977. Climatically perturbed temperature gradients and their effect on regional and continental heat flow means. Tectonophysics, Vol. 41, No. I, p. I 7-39.

Clough, J. W., and Hansen, B. L. 1979. The Ross Ice Shelf Project. Science, Vol. 203, No. 4379, p. 433-34.

Ho, C. Y., and others. 1978. Thermal conductivity of rocks, by C. Y. Ho, R. W. Powell, and P. E. Liley. (In Weast, R. C., and Astle, M. J., ed. CRC handbook of chemistry and physics. Fifty-ninth edition. West Palm Beach, Florida, CRC Press, Inc., p. E-I6.)

Martin, P. J., and Sanderson, T. J. O. 1980. Morphology and dynamics of ice rises. Fournal of Glaciology, Vol. 25, No. 91, p. 33-45.

Robertson, J. D., and others. In press. Sea bottom topography and crustal structure below the Ross Ice Shelf, Antarctica, by J. D. Robertson, C. R. Bentley, J. W. Clough, and L. L. Greischar. (In Craddock, C., ed. Antarctic geoscience. Proceedings of the third Symposium on Antarctic Geology and Geophysics, Madison, 22-27 August, 1977. Madison, University of Wisconsin Press.)

Rose, K. E. 1979. Characteristics of ice flow in Marie Byrd Land, Antarctica. Fournal of Glaciology, Vol. 24, No. 9o, p. 63-75.

Thomas, R. H., and Bentley, C. R. 1978. The equilibrium state of the eastern half of the Ross Ice Shelf. Fournal of Glaciology, Vol. 20, No. 84, p. 509-18.

Thomas, R. H., and others. 1980 . The creep of ice, geothermal heat flow, and Roosevelt Island, Antarctica, by R. H. Thomas, D. R. MacAyeal, C. R. Bentley, and J. L. Clapp. Fournal of Glaciology, Vol. 25, No. 9i, p. $47-60$. 